\title{
Comparison of Red Cell Distribution Width (RDW) Value in Congestive Heart Failure (CHF) Patients with Normal Persons
}

\author{
Marhani Yunita ${ }^{1}$, Herman Hariman ${ }^{2}$ \\ ${ }^{1,2}$ Department of Clinical Pathology, Faculty of Medicine of University of Sumatera Utara / General Hospital \\ Haji Adam Malik Medan, Indonesia.
}

Corresponding Author: Marhani Yunita

\begin{abstract}
Congestive Heart Failure (CHF) is a complex clinical symptom that is often characterized by structural abnormalities or cardiac dysfunction that impairs the ability of the left ventricle (LV) to fill or pump blood, especially during physical activity. Red Cell Distribution Width (RDW) is a simple, fast, inexpensive and direct hematological parameter, which reflects the level of anisocytosis in vivo. The association between impaired hematopoiesis and cardiac dysfunction is based on the fact that many different conditions are associated with increased heterogeneity of erythrocyte volume, which can be concurrently present in patients with heart failure, while anisocytosis can also directly contribute to the development and worsening of heart failure. This study aims to provide a comparison of RDW values between $\mathrm{CHF}$ patients and normal people. This study uses a case control study design where as many as 20 people with $\mathrm{CHF}$ will be compared their RDW values with 20 normal people. From a total of 40 patients, the average RDW value in CHF patients was $17.7 \pm 2.4$ higher than the average RDW value for normal people was $12.6 \pm 0.4$ and from the results of statistical analysis using the Independent Student $t$ test obtained $\mathrm{p}$ value $<0.001$. There is a significant difference between the RDW values of $\mathrm{CHF}$ patients compared to normal people.
\end{abstract}

Keywords: Congestive Heart Failure, CHF, Red Cell Distribution Width, RDW

\section{BACKGROUND}

Heart disease in adults that is often encountered is coronary heart disease and heart failure. The prevalence of heart failure increases exponentially with age, which is $6-10 \%$ in people over 65 years of age. According to $\mathrm{WHO}$ in 2016 , as many as 17.5 million people died from cardiovascular disease in 2008, representing $31 \%$ of deaths in the world.

The incidence of approximately five million American patients with heart failure increases each year by 550,000 events. CHF is a heart failure disease accompanied by fluid accumulation characterized by edema, liver enlargement, pulmonary edema, and jugular venous distention.2 While in developing countries 400,000 to 700,000 per year. Heart failure in the United States is the most common cause in patients receiving hospital treatment with \pm 5 million sufferers. There are at least $2.3 \%$ of the adult population aged 45 years who suffer from heart failure and increased to $4 \%$ at the age of 75 years. More than 550,000 people are diagnosed with heart failure each year and it is the cause of 287,200 deaths per year. Currently, the prevalence of heart failure in developing countries is around $2 \%$.

Heart failure is the inability of the heart to pump enough blood throughout the body, which is characterized by shortness of breath during activities and/or when sleeping on your back without a pillow, 
and/or swollen lower limbs. The prevalence of heart failure based on having been diagnosed by a doctor in Indonesia is $0.13 \%$, and based on a doctor's diagnosis or symptoms is $0.3 \%$

$\mathrm{CHF}$ is considered a systemic disease based on chronic inflammatory status. In the setting of long-term CHF, other organ systems are also involved. Facilities to assess heart failure in Indonesia, such as echocardiography, are not always available in peripheral hospitals, so other markers are needed as an accessible and inexpensive alternative. Laboratory examination, imaging, and clinical signs are the three most widely used categories in estimating the prognosis of heart failure.

In recent years, many studies have analyzed the role of Red Cell Distribution Width (RDW) as a prognostic indicator of heart failure. RDW is not essentially a molecule, but a statistical concept that measures variations in the size of red blood cells. RDW was first introduced as a tool for the working diagnosis of normocytic anemia and other researchers have found that the prognostic value of RDW is superior to anemia or severity.

Red cell distribution width is a measurement of variation in erythrocyte size (anisocytosis). Elevated levels of RDW in adults are associated with an increased risk of all-cause and cardiovascular mortality in patients with heart failure and other chronic diseases. To date, there have been many studies in the adult population examining the prognostic value of RDW in patients with heart failure, but the results have been inconsistent.

Based on the above concept, the researcher wants to examine the comparison between the RDW Value in CHF patients with normal people so that it can be a standard reference to support the diagnosis of CHF.

This study aims to compare the RDW value between CHF patients and normal people, so that it can be used as an additional marker of CHF diagnosis at a lower cost and more specific that can be used in simple facilities without reducing its accuracy.

\section{RESEARCH METHODS}

The study was conducted at the Department of Clinical Pathology, USU Medical Faculty / RSUP H. Adam Malik Medan in collaboration with the Department of Cardiology, USU Medical Faculty / RSUP H. Adam Malik Medan. This study was an observational study with case control data collection methods. This research was conducted from April to June 2019. The study subjects were men and women aged > 18 years and the controls were healthy people aged > 18 years. The research subjects were $20 \mathrm{CHF}$ patients and 20 healthy people. Routine blood tests using K2EDTA blood samples were examined using the automatic cell counter analyzer Sysmex XN-1000, this tool uses a combination of electric impedance and flow cytometry.

Data analysis was performed using SPSS (Statistical Package for Social Sciences, Chicago, IL, USA) software for Windows. The description of the characteristics of the research subjects is presented in tabulated form and described. Differences in RDW values in CHF patients with normal people were tested using Pearson's Independent student $t$-test if the data were normally distributed. If the data is not normally distributed, the Mann Whitney $\mathrm{U}$ test is used. All statistical tests with $\mathrm{p}$ value $<0.05$ were considered significant.

\section{RESULTS AND DISCUSSION}

This study used a case sample of 20 patients with CHF who were treated in the cardiology ward of H. Adam Malik Hospital Medan and 20 normal people as controls. 28 people from the total sample were male $(70 \%)$ and the remaining $12(30 \%)$ were female. All participants had a mean age of 55.95 years with a standard deviation of 5.84 years. The youngest age is 45 years and the oldest is 67 years. The most ethnic groups were Batak 30 patients $(75 \%)$ and 
Javanese 6 patients $(15 \%)$ and Malay 4 patients (10\%).(Table 1)

Table 1. Patient Characteristics (n=15)

\begin{tabular}{|l|c|}
\hline Variabel & $\mathbf{n}(\boldsymbol{\%})$ \\
\hline Gender & \\
\hline Male (n\%) & $28(70 \%)$ \\
\hline Female (n\%) & $12(30 \%)$ \\
Ethnic (n\%) & $30(75 \%)$ \\
Batak & $6(15 \%)$ \\
Jawa & $4(10 \%)$ \\
Melayu & $55,95 \pm 5,84 / 45 / 67$ \\
\hline Ages (Mean \pm SD / Min / Max) & \\
\hline
\end{tabular}

Table 2. Characteristics of Initial Measurement
\begin{tabular}{|l|l|l|}
\hline Group & Rdw value (Mean \pm SD) & Min - Max \\
\hline CHF & $17,70 \pm 2,40$ & $14,6-23,6$ \\
\hline Normal Person & $12,58 \pm 0,38$ & $11,8-13,2$ \\
\hline
\end{tabular}

In the initial measurement, the minimum RDW value in the case group, namely CHF patients was 14.6 and the maximum value was 23.6 with a mean of 17.70 and a standard deviation of 2.40 . Meanwhile, the minimum level of RDW in the control group, namely normal people, was 11.8 and the maximum value was 13.2 with a mean of 12.58 and a standard deviation of 0.38 .

Table 3. Comparative analysis of RDW values of CHF patients with normal people

\begin{tabular}{|l|l|l|l|}
\hline & Patient CHF & Normal Person & p Value \\
\hline RDW value & $17,70 \pm 2,40$ & $12,58 \pm 0,38$ & 0,001 \\
\hline
\end{tabular}

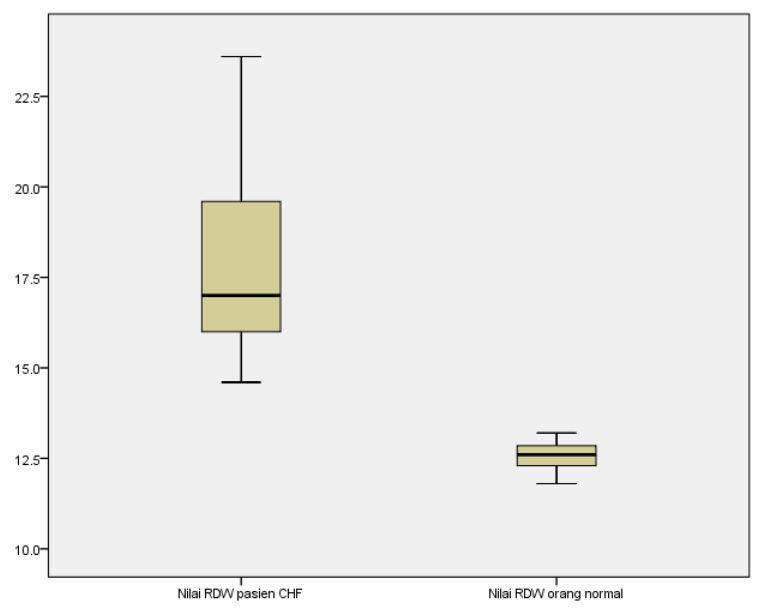

Independent Student t-test statistical test showed that there was a very significant difference between the RDW values of CHF patients and normal people $(\mathrm{p}=0.001)$.

This is in line with the chronic inflammatory process in CHF patients, where the chronic inflammatory process will release various cytokines that will affect erythropoiesis through various pathways so that it can affect the RDW value.

There are several limitations in our study, firstly the research sample that we used was still small. In addition, we only compared it with normal people which makes it not yet usable to predict the severity or used in the prognostic value of $\mathrm{CHF}$ disease in the future.

\section{CONCLUSIONS}

In this study it can be concluded that the RDW value in CHF patients is significantly different from normal people. Based on the results of this study, it can be recommended to conduct further research on the RDW value associated with the severity of CHF and its prognostic value.

\section{Acknowledgement: None}

\section{Conflict of Interest: None}

\section{Source of Funding: None}

\section{Ethical Approval: Approved}

\section{REFERENCES}

1. Anderson, J.L., Ronnow, B.S., Horne, B.D., Carlquist, J.F., May, H.T., Bair, T.L., Jensen, K.R., Muhlestein, J.B. and Group, I.H.C.I.S., 2007. Usefulness of a complete blood count-derived risk score to predict incident mortality in patients with suspected cardiovascular disease. The American journal of cardiology, 99(2), pp.169-174.

2. Kemenkes RI, 2013. Riset Kesehatan Dasar Riskesdas 2013, Badan Penelitian dan Pengembangan Kementerian Kesehatan RI Tahun 2013,viewed27 Agustus 2018,http://www.litbang.depkes.go.id/sites/ download/rkd2013/Laporan_Riskesdas2013 .PDF.

3. Levy, D., Kenchaiah, S., Larson, M.G., Benjamin, E.J., Kupka, M.J., Ho, K.K., Murabito, J.M. and Vasan, R.S., 2002. Long-term trends in the incidence of and survival with heart failure. New England Journal of Medicine, 347(18), pp.13971402. 
4. Thakur, V., Fouron, J.C., Mertens, L. and Jaeggi, E.T., 2013. Diagnosis and management of fetal heart failure. Canadian Journal of Cardiology, 29(7), pp.759-767.

5. Van Kimmenade, R.R., Mohammed, A.A., Uthamalingam, S., van der Meer, P., Felker, G.M. and Januzzi Jr, J.L., 2010. Red blood cell distribution width and 1-year mortality in acute heart failure. European journal of heart failure, 12(2), pp.129-136.
6. WHO, 2016. Prevention of Cardiovascular Disease. WHO Epidemologi Sub Region AFRD and AFRE. Genewa

How to cite this article: Yunita M, Hariman $\mathrm{H}$. Comparison of red cell distribution width (RDW) value in congestive heart failure (CHF) patients with normal persons. International Journal of Research and Review. 2021; 8(8): 27-30. DOI: https://doi. org/10.52403/ijrr.20210806 